\title{
Chemoorganotrophic bacteria isolated from biodeteriorated surfaces in cave and catacombs
}

Filomena De Leo ${ }^{1}$, Agnese Iero ${ }^{1}$, Gabrielle Zammit ${ }^{2}$, and Clara E. Urzi ${ }^{1}$

\begin{abstract}
:
De Leo F., lero A., Zammit G. and Urzì C. 2012. Chemoorganotrophic bacteria isolated from biodeteriorated surfaces in cave and catacombs. International Journal of Speleology, 41(2), 125-136 Tampa, FL (USA). ISSN 0392-6672.

http://dx.doi.org/10.5038/1827-806X.41.2.1

The main objective of this work was the comparative analysis of a large number of bacterial strains isolated from biodeteriorated surfaces in three different sites, namely the catacombs of St. Callistus in Rome, Italy, the catacombs dedicated to St. Agatha in Rabat, Malta and the Cave of Bats in Zuheros, Spain. Our results showed that even considering only culturable chemoorganotrophic bacteria the variability is very high, reflecting the great variety of microhabitats present. Hence any strategies to prevent, control or eliminate the biofilm-embedded microbiota from an archeological surface should take into account a number of considerations as stipulated in our study.
\end{abstract}

Keywords: biofilm; catacombs; caves; chemoorganotrophic bacteria; clustering; 16S rDNA sequencing

Received 20 October 2011; Revised 2 January 2012; Accepted 10 January 2012

\section{INTRODUCTION}

Any study of microbial communities colonizing biodeteriorated surfaces should involve a combination of several analytical techniques such as microscopy, culture techniques, biochemical tests and molecular tools, which are designed to give complementary results. Each individual technique while having its own limitations, contributes the necessary information to provide a better understanding of the microbial community as a whole and its role in the deterioration of inorganic and/or organic substrata (Urzì et al., 2003).

Culture-based techniques are selective due to the limited choice of media used for the cultivation of microorganisms, and because the viable and culturable microflora (VCM) may be restricted to 1 to $5 \%$ of the whole population (Amann, 2000). However, the culture-based approach offers the possibility to isolate and thus analyze a great number of strains (Donachie et al.,2007). It is then possible to study the isolated strains, to cluster them into operational taxonomic units (OTUs), to compare different microbial communities on the basis of types of cultivable bacteria isolated in term of richness and the frequency of isolates, distribution or relative abundance of types. Furthermore, cultivation-based techniques in association with other complementary molecular techniques give a good idea of the "microorganisms in action" because,

${ }^{1}$ Department of Life Sciences, "M. Malpighi” University of Messina, Viale F. Stagno d'Alcontres 31, 98166 Messina, Italy; Corresponding author: Clara Urzì (clara.urzi@unime.it)

${ }^{2}$ Department of Physiology and Biochemistry, University of Malta, Biomedical Sciences Building, Msida, MSD2620, Malta. in most cases, strains that grow in culture can prove to be metabolically active microorganisms, if the environment provides the required conditions. This is particularly true in the conservation of indoor Cultural Heritage monuments where most of the dangerous microorganisms for the artefact itself (biodeteriogens) are those that grow epilithically on the surfaces; they form a biofilm and cover areas that are the most valuable because are sculptured or painted.

Very often, in fact, stone surfaces are hidden by unaesthetic colonization due to phototrophic and chemoorganotrophic biofilms (Roldán \& HernándezMariné, 2009), and it is a common practice to treat those surfaces with biocides in order to eradicate the biodeteriogens present (Nugari et al., 2009).

However, biocides commonly applied on valuable surfaces are not always completely successful to eradicate the complex community within the biofilm (Salvadori \& Charola, 2011). Thus it is important to study the culturable fraction of microorganisms in order to test in the laboratory if the chemical compounds used are effective against the deteriogenic microflora. For this reason, when dealing with a large number of strains, it is imperative to use a reliable and easily implemented technique to group the strains into homogeneous clusters and reduce the amount of work to be carried out to characterize the isolates.

In this research study a large number of cultivable bacteria isolated from three sites were analyzed through a multi-step approach that included the frequency of types of colony, preliminary description of their micro-morphology, clusterization of all the isolates via ITS-PCR, and the identification of selected strains within each cluster. 


\section{Areas of study}

\section{MATERIAL AND METHODS}

Sampling campaigns were carried out in the Ocean Cubicle (CSC13), inside the Catacombs of St. Callistus (Rome, Italy), in the Cave of Bats (Z1 to Z8) close to the village of Zuheros (Córdoba, Southern Spain) in the frame of the research activity carried out during the European project CATS (EVK4-200000028), and in different areas of St. Agatha's Crypt and Catacombs (SA) in Rabat, Malta, during the activity carried out in the framework of a COST Action G8 scientific mission (COST-STSM-G8-1435) (Zammit et al., 2009).

In both catacombs the relative humidity ( $\mathrm{RH})$ was always above $90 \%$ while the Mediterranean climate of the areas did not influence the inner temperature of the catacombs due to their deep location (range 15$20^{\circ} \mathrm{C}$ ) (Albertano et al., 2003; Zammit et al., 2009). The Cave of Bats presented a $\mathrm{RH}$ variable from 95 (inner part of the cave) to $56 \%$ (near the exit) and an average temperature between 8 and $14^{\circ} \mathrm{C}$, depending on the area, at the time of sampling (Urzi et al., 2010). Samples were taken aseptically in correspondence to alterations on rock surface described as black spots, green patina, whitish/grey patinas with scalpel and/ or adhesive tape as shown in Table 1.

\section{Cultural analyses}

For the isolation of chemoorganotrophic microorganisms samples were processed as described by Urzi et al. (2010). The following agarized media were used: BRII medium (Bunt and Rovira, 1955 modified as reported in Urzi et al., 2001), SC (Starch Casein $\mathrm{KNO}_{3}$ agar, Kuster \& Williams, 1964) and R2A (Reasoner and Geldreich, 1985 Oxoid); in all media 0.05\% cycloheximide was added to avoid/limit the growth of unwanted fungal contaminants. Incubation was carried out at $28^{\circ} \mathrm{C}$ up to one month to allow slow-growing strains. At the end of incubation time, enumeration of microorganisms as $\mathrm{cfu} / \mathrm{g}$ of sample was carried out and randomly chosen bacterial strains $(10 / 20$ colonies per sample) were isolated on Trypticase Soy Agar (TSA, Oxoid). The bacterial isolates were maintained on TSA (Tryptone, Soy Agar) or GYM (Glucose, Yeast extract, Malt extract, Agar).

Bacterial strains were preliminarily characterized by their macro- and micro-morphology, their Gram staining, catalase and oxidase activity. The strains were then clustered on the basis of their ITS profiles. Randomly selected strains belonging to the same profile were identified through $16 \mathrm{~S}$ rDNA partial sequencing.

Table 1. Samples, modality of sampling type of alteration, surface in three site studied. Presence and/or absence phototrophic organisms was also considered

\begin{tabular}{|c|c|c|c|}
\hline Sampling site & Alteration type & $\begin{array}{l}\text { Type of substrate/ } \\
\text { Sampling modality }\end{array}$ & $\begin{array}{c}\text { Presence of } \\
\text { photototrophs }\end{array}$ \\
\hline CSC13a, CSC13b, CSC13c & Whitish/grey patina & Tufa/Scalpel & $\mathrm{N}$ \\
\hline CSC13i, CSC13f & $\begin{array}{l}\text { White patinas on top of } \\
\text { green biofilm }\end{array}$ & Fresco/Adhesive tape & $\mathrm{Y}$ \\
\hline CSC13h & $\begin{array}{l}\text { Interface between green } \\
\text { biofilm and white patina }\end{array}$ & Fresco/Adhesive Tape & $\mathrm{Y}$ \\
\hline CSC13d & $\begin{array}{l}\text { no apparent colonization } \\
\text { after } 6 \text { months from biocide } \\
\text { treatment }\end{array}$ & Fresco/Adhesive tape & $\mathrm{Y}$ \\
\hline CSC13e, & Dark Green biofilm & Fresco/Adhesive tape & $\mathrm{Y}$ \\
\hline CSC13g & Black spots & Tufa/Adhesive tape & $\mathrm{Y}$ \\
\hline $\mathrm{Z1a}$ & Dark grey spots & $\begin{array}{l}\text { Limestone/Scalpel-Adhesive } \\
\text { tape }\end{array}$ & Y \\
\hline$Z 1 b$ & Red spots & $\begin{array}{l}\text { Limestone/Scalpel-Adhesive } \\
\text { tape }\end{array}$ & $\mathrm{Y}$ \\
\hline $\mathrm{Z3b}, \mathrm{Z3c}$ & Black alteration & $\begin{array}{l}\text { Limestone/Scalpel-Adhesive } \\
\text { tape }\end{array}$ & $\mathrm{Y}$ \\
\hline $\begin{array}{l}\text { Z2a, Z2b, Z3a, Z4a, Z4b, Z5a, } \\
\text { Z5b, Z5d, Z6a, Z6b, Z7a, Z8a }\end{array}$ & Green patina & $\begin{array}{l}\text { Limestone/Scalpel-Adhesive } \\
\text { tape }\end{array}$ & $\mathrm{Y}$ \\
\hline SA1, SA14, SA15, SA16, SA20 & Reddish spots & Limestone/Adhesive tape & $\mathrm{Y}$ \\
\hline $\begin{array}{l}\text { SA2, SA3, SA8, SA9, SA13, } \\
\text { SA17, SA18 }\end{array}$ & Green patina & $\begin{array}{l}\text { Limestone, Plaster/Adhesive } \\
\text { tape }\end{array}$ & $\mathrm{Y}$ \\
\hline SA4, SA7, SA19, SA23 & Whitish/grey patina & $\begin{array}{l}\text { Limestone/Scalpel-Adhesive } \\
\text { tape }\end{array}$ & $\mathrm{N}$ \\
\hline SA10, SA12 & Dark grey spots & Plaster, Fresco/Adhesive tape & $\mathrm{Y}$ \\
\hline SA6 & Yellowish spots & Plaster/Adhesive tape & $\mathrm{N}$ \\
\hline
\end{tabular}


$\mathrm{CSC} 13$

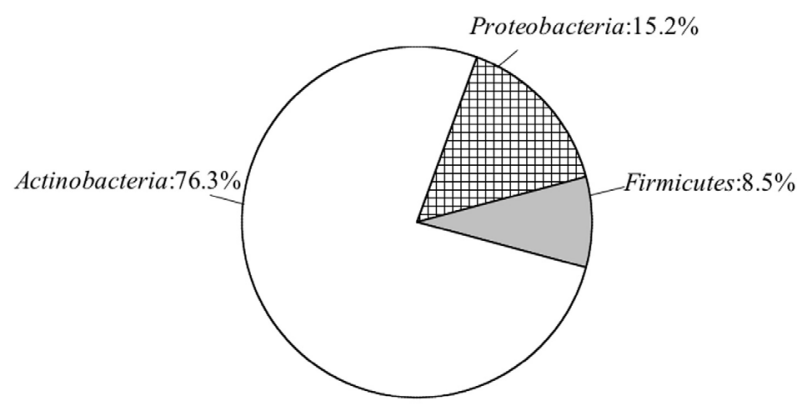

a

Cave of Bats

Proteobacteria: $9.2 \%$

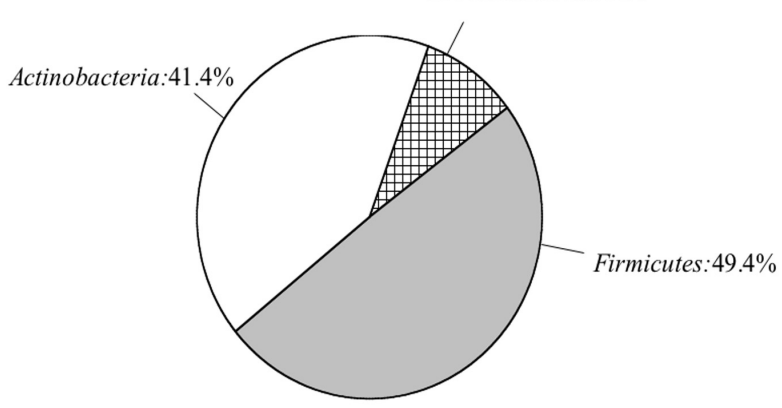

C

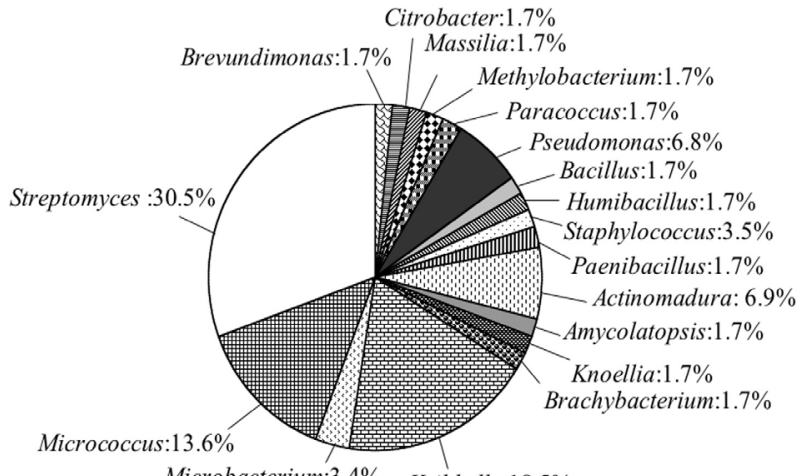

Microbacterium: $3.4 \% \quad$ Kribbella: $18.5 \%$

b

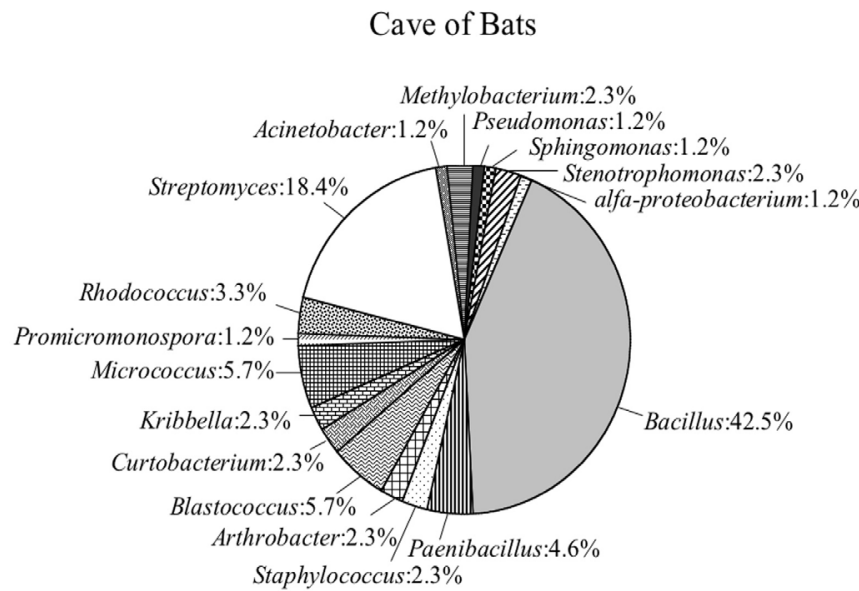

d

St. Agatha catacombs

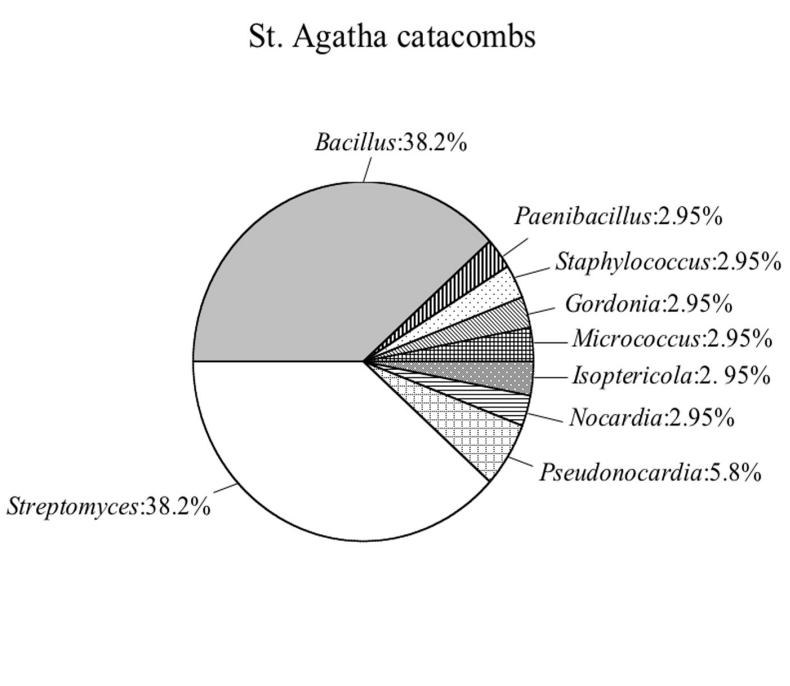

f

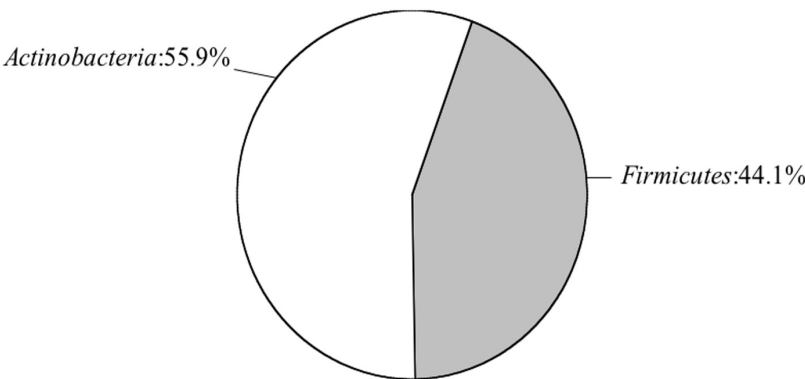

Plate 1. Graphic representation of distribution of bacteria isolated from St. Callistus catacombs (a, b), Cave of Bats (c, d), and St. Agatha catacombs (e, f). On the left the different classes of bacteria isolated ( $a, c$ and $e)$; on the right are represented the different genera and the respective percentage of isolation ( $b, d$ and $f$ ). 


\section{Bacterial strains}

180 strains were isolated and considered in this study. In particular, 59 bacterial strains were isolated from biofilm samples taken from the Ocean Cubicle (CSC13), in the St. Callistus Catacombs in Rome, Italy, 87 strains were isolated from 16 samples taken from the Cave of Bats in Zuheros, Spain and 34 strains were isolated from 19 samples taken from St. Agatha Crypt and Catacombs in Malta.

\section{ITS-PCR}

Genomic DNA was extracted from all the bacteria, as described by Rainey and co-workers (1996), after growth of the strains on TSA medium for 7 days.

Amplification of ITS was carried out using the primer pair F1492 (5'AAGTCGTAACAAGGTAGCCG3') and R188 (5'GGTACTTAGAGTTTTCAGTTC) (Gurtler \& Stanisich, 1996) in a final volume of $50 \mu 1$ containing 2.5 U of Taq DNA polymerase (Pharmacia Biotech, Italy), $200 \mathrm{mM}$ (each) deoxynucleoside triphosphates (dNTPs), $0.2 \mathrm{mM}$ of each primer in $1 \mathrm{X}$ reaction buffer [1.5 mM $\mathrm{MgCl}_{2}, 50 \mathrm{mM} \mathrm{KCl}$, Tris- $\mathrm{HCl}(\mathrm{pH}$ 9.0)] and $100 \mathrm{ng}$ of DNA with a DNA thermal cycler 2400 (Perkin Elmer Cetus, Norwalk, USA). The profile temperature was as follows: initial denaturation at $95{ }^{\circ} \mathrm{C}$ for $5 \mathrm{~min}, 35$ cycles of denaturation at $94^{\circ} \mathrm{C}$ for $1 \mathrm{~min}$, annealing at $54{ }^{\circ} \mathrm{C}$ for $1 \mathrm{~min}$ and extension at $72{ }^{\circ} \mathrm{C}$ for $90 \mathrm{~s}$, and final extension at $72{ }^{\circ} \mathrm{C}$ for $7 \mathrm{~min}$.

The PCR products were purified through a QIAquick PCR Purification kit according to the supplier's instructions (Qiagen, Milan, Italy) and then separated on a

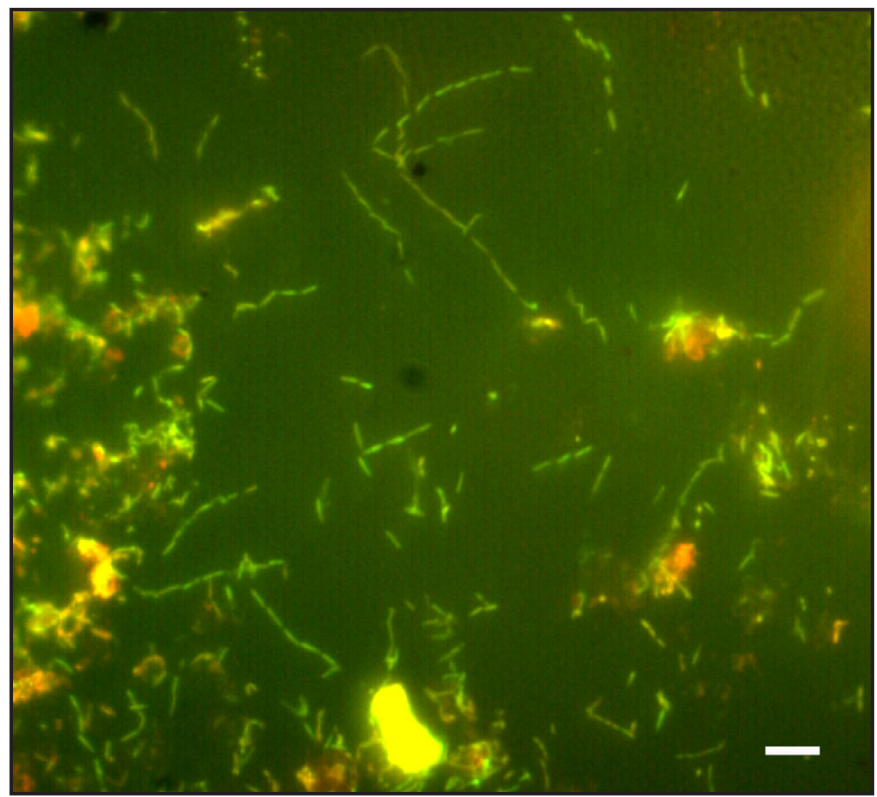

Fig. 1. Direct observation under epifluorescent microscopy of adhesive tape sample SA7 taken in Malta Catacombs. Chain of rod shaped spore forming bacteria were visible after Acridine orange staining. Inorganic material showed a bright self-fluorescence. Bar is $10 \mu \mathrm{m}$.

$2 \%$ agarose gel stained with ethidium bromide. Profiles were examined using Kodak Digital Science 1d 2.0 software and the analysis was carried out on the basis of the number and size of bands as compared to a 50 bp DNA ladder marker (Invitrogen, Milan, Italy).

Table 2. Proteobacteria isolated from the Ocean Cubicle in St. Callistus Catacombs and from Zuheros Cave. Strains were clusterized on the basis of their ITS-PCR profile.

\begin{tabular}{|c|c|c|c|c|}
\hline $\begin{array}{l}\text { Nr. ITS } \\
\text { clusters }\end{array}$ & $\operatorname{csc13}$ & Zuheros* & St. Agatha & $\begin{array}{l}\text { Nearest relative on the basis of } \\
16 \text { SDNA sequences similarity\# }\end{array}$ \\
\hline 1 & & $\underline{Z 5 d 4}$ & & Acinetobacter lwofii FJ529917 (98.2\%) \\
\hline 1 & $\underline{\mathrm{CSC} 13 \mathrm{~b} 9}$ & & & Brevundimonas diminuta X87274 (99.9\%) \\
\hline 1 & $\underline{\mathrm{CSC} 13 \mathrm{i} 3}$ & & & Citrobacter sp. EU341320 (99.3\%) \\
\hline 1 & CSC13a22 & & & Massilia timonae AY157761 (99.9\%) \\
\hline 1 & & $\underline{Z 1 b 10}$ & & Methylobacterium extorquens AJ400917 (99\%) \\
\hline 1 & $\underline{\mathrm{CSC} 13 \mathrm{~b} 2}$ & & & Methylobacterium populi CP001029 (99.5\%) \\
\hline 1 & & $\underline{Z 7 a 8}$ & & Methylobacterium sp. AJ400934 (99.5\%) \\
\hline 1 & $\underline{\operatorname{CSC} 13 \mathrm{~d} 7}$ & & & Paracoccus yeeii AY014173 (100\%) \\
\hline 2 & $\begin{array}{l}\text { CSC13g4 } \\
\text { CSC13g2 } \\
\end{array}$ & & & Pseudomonas putida AF094736 (100\%) \\
\hline 1 & & $\underline{Z 6 a 7}$ & & Pseudomonas sp. ABO13843 (98.6\%) \\
\hline 1 & $\frac{\text { CSC13g7 }}{\text { CSC13i3 }}$ & & & Pseudomonas stutzeri CP000304 (99.9\%) \\
\hline 1 & & $\underline{Z 2 b 7}$ & & Sphingomonas aerolata AJ429240 (98.8\%) \\
\hline 1 & & $\begin{array}{l}Z 6 a 2 \\
\underline{Z 6 a 6} \\
\end{array}$ & & Stenotrophomonas maltophila AJ295673 (98.3\%-100\%) \\
\hline 1 & & $\underline{Z 1 a 13}$ & & Uncultured alpha proteobacteria AY133099 (99.2\%) \\
\hline
\end{tabular}

Underlined strains were those identified by sequencing of 16S rDNA; (*) data taken from Urzì et al., (2010). 


\section{S rDNA sequencing}

Due to the reliability of the ITS-PCR method as already reported by Pangallo et al. (2009), identification procedures were carried out on randomly selected strains belonging to each cluster (see underlined strains in Table 2 and Appendices 1-3).

Genomic DNA was extracted as described before and amplification was carried out using the universal primers F27 (5'AGAGTTTGATCCTGGCTCAG3') and R1492 (5'CGGCTACCTTGTTACGACTT3') (Life Technologies, Italy) in a final volume of $100 \mathrm{ml}$ containing 2.5 U of Taq DNA polymerase (Pharmacia Biotech, Italy), $200 \mathrm{mM}$ (each) deoxynucleoside triphosphates (dNTPs), $0.2 \mathrm{mM}$ of each primer in $1 \mathrm{X}$ reaction buffer [1.5 mM $\mathrm{MgCl}_{2}, 50 \mathrm{mM} \mathrm{KCl}$, Tris- $\mathrm{HCl}(\mathrm{pH} \mathrm{9.0)]} \mathrm{and}$ $100 \mathrm{ng}$ of DNA with a DNA thermal cycler 2400 (Perkin Elmer Cetus, Norwalk, USA). The profile temperature was as follows: initial denaturation at 95 ${ }^{\circ} \mathrm{C}$ for $2 \mathrm{~min}, 35$ cycles of denaturation at $94{ }^{\circ} \mathrm{C}$ for $1 \mathrm{~min}$, annealing at $55{ }^{\circ} \mathrm{C}$ for $1 \mathrm{~min}$ and extension at $72{ }^{\circ} \mathrm{C}$ for $90 \mathrm{~s}$, and final extension at $72{ }^{\circ} \mathrm{C}$ for 7 min and cooling at $4{ }^{\circ} \mathrm{C}$. The presence and yield of specific PCR products, approximately 1500 bp long, were visualized on agarose $(1 \%)$ gel electrophoresis after staining with ethidium bromide $(50 \mathrm{ng} / \mathrm{ml})$ for $30 \mathrm{~min}$ at $7 \mathrm{~V} / \mathrm{cm}$.

The PCR products obtained, were purified using a QIAquick PCR Purification kit according to the supplier's instructions (Qiagen, Milan, Italy), and sequenced by GENELAB (Rome, Italy), using the universal primer F27.

Sequences obtained were compared with those published on the EMBL-EBI databank (http://www. ebi.ac.uk/fasta33/nucleotide.html) and alignment of sequences was carried using ClustalW software (http://www.ebi.ac.uk/Tools/clustalw2/index.html).

\section{RESULTS}

83 PCR profiles were obtained after amplification of the ITS region, followed by separation of the PCR products by electrophoresis. Taxonomic assignment for each ITS-PCR profile was carried out after sequencing of the $16 \mathrm{~S}$ rDNA of the randomly selected species from each cluster as reported in Table 2 and Appendices 1-3.

The comparative analysis of microflora evidenced that within each habitat considered, the composition, structure and distribution of strains was quite different.

In fact, on the basis of taxonomic assignment, the bacteria belonged to the Classes of Proteobacteria, Firmicutes and Actinobacteria (Plate 1 a, c, e) had a different percentage in each of the three sites. In particular the following observations were made:

Proteobacteria constituted a small fraction of the bacteria isolated. In fact, they ranged between $9.2 \%$ and $15.2 \%$ respectively in Cave of Bats and CSC 13 while they were not isolated from the samples taken from St. Agatha catacombs.

Firmicutes were isolated in high percentages from the microbial community sampled from the Cave of Bats (49.4\%) and St Agatha catacombs (44.1\%), while in the CSC13 they were found to be present in very low percentage $(8.5 \%)$.
In the catacomb sites, members of the Actinobacteria were the predominant microorganisms, especially in the catacombs of St. Callistus (76.3\%), but also at St Agatha's (55.9\%). At the Cave of Bats, the percentage of isolated Actinobacteria was lower than Firmicutes (41.4\% vs. 49.4\%).

As far as the frequency and relative abundance of genera in each site studied is concerned, the results are reported below and shown in Plate 1.

\section{St. Callistus Catacombs}

According to ITS-PCR analyses, the 59 bacterial strains fell in 30 different profiles and on the basis of the sequencing data into 26 OTUs (Plate 1a, b).

Among the Actinobacteria, the majority of strains belonged to the genera Streptomyces (30.5\%), Kribbella (18.5\%), Micrococcus (13.6\%), Actinomadura (6.9\%) and Microbacterium (3.4\%); other genera were isolated with a lower frequency $(1.7 \%)$ and their occurrence was considered to be occasional findings. Two new species of the genus Kribbella, namely $K$. catacumbae and $K$. sancticallisti were described from this site (Urzi et al., 2008). Among the Gram negative (15.2\% of the total of isolated strains), Pseudomonas was the most common genus found $(6.8 \%)$.

Firmicutes, namely species from the genera $\mathrm{Ba}$ cillus, Paenibacillus, Humibacillus, and Staphylococcus were occasionally found $(1.7 \%-3.4 \%)$.

\section{Cave of Bats}

According to ITS-PCR analyses, the 87 strains fell into 37 different profiles and 32 OTUs (Table 2, Appendices 1-3 and Plate 1c, d).

The majority of bacteria were Gram positive strains $(90.6 \%)$ belonging to Firmicutes in the genera Bacillus (42.5\%) and Paenibacillus (4.6\%), and to Actinobacteria $(41.2 \%)$ in the genera Streptomyces (18.4\%) Blastococcus (5.7\%), Micrococcus (5.7\%), and Rhodococcus (3.3\%).

Occasional found were bacteria of the genera Arthrobacter, Curtobacterium, Kribbella, Promicromonospora and Staphylococcus (2.3\%). Among the Gram negatives $(9.4 \%$ of total strains isolated) the strains belonging to the genera of Methylobacterium, (AlphaProteobacteria), Pseudomonas, Sphingomonas, and Stenotrophomonas (Gamma-Proteobacteria) were considered as occasional (1.2-2.3\%). As reported in a previous paper (Urzi et al., 2010) it was observed that only a few species of Bacillus were found in almost all samples, while other bacteria were localized especially on those samples collected in places near to the entrance.

\section{St. Agatha's Catacombs}

According to ITS-PCR analyses, the 34 isolated strains clustered into 20 different profiles and 18 OTUs.

No Proteobacteria were isolated. The majority of cultured species belonged to the genus Bacillus (37.3\%), followed by Streptomyces spp. (38.2\%) and Pseudonocardia (5.8\%) while Paenibacillus, Isoptericola Gordonia, Micrococcus, and Nocardia were less frequently isolated $(2.95 \%)$. The spore-forming $B$. aquimaris were the most widespread. 


\section{DISCUSSION}

The main aim of this study was the analysis of a large number of chemoorganotrophic bacteria colonizing three cave/catacomb sites belonging to different geographic regions in the Mediterranean area, which were characterized by well documented microclimatic parameters and biodeterioration patterns (Albertano et al., 2003; Zammit et al., 2009).

Caves and catacombs are biotopes whose surfaces are generally poor in nutrients, with relatively stable and low temperature with high relative humidity and mineral concentrations that provide various ecological niches for highly specialized microorganisms. It is a well known fact that chemoorganotrophic bacteria, mainly Actinobacteria such as Streptomyces, Micrococcus, Arthrobacter, Brevibacterium, Nocardia (Groth \& Saiz-Jimenez, 1999; Laiz et al., 2003) are common inhabitants of stone surfaces in subterranean environments. Their presence in caves and catacombs has caused evident biodeterioration phenomena on the archaeological surfaces due to the formation of patinas and biofilms in which either phototrophic microorganisms or chemorganotrophic bacteria can prevail depending on the presence/absence of light sources (Albertano et al., 2003; Urzì et al., 2010; Zammit et al., 2011a).

However, as evidenced in the present research, apparently similar alterations (e.g. those described by whitish/grey patinas) can be due to different kind of bacteria that are often seen under the microscope and described as filamentous bacteria. In the past, these alterations were considered caused almost exclusively by the growth of different species of Streptomyces (Agarossi et al., 1985). We found, however, that despite their apparent homogeneity they harboured (or were due to) different types of bacteria (as shown in Table 3). Furthermore, both in caves and catacombs, it is common to find surfaces widely covered by white fluffy (cotton like) biofilm in which mineral precipitates are associated with bacteria, especially Bacillus (SanchezMoral et al., 2003; Cuezva et al., 2009), and several studies show that a number of strains may actively participate in the precipitation of mineral phases (Urzi et al. 1999; Sanchez-Moral et al., 2003; Zammit et al.

Table 3. Bacteria found in correspondence of whitish/grey patinas with no apparent cyanobacteria colonization.

\begin{tabular}{|c|c|c|}
\hline & Samples & Bacterial strains \\
\hline \multirow{3}{*}{ 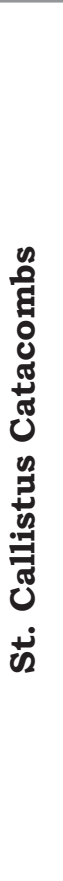 } & Csc13a & $\begin{array}{l}\text { Massilia timonae } \\
\text { Humibacillus xanthopallidus } \\
\text { Staphylococcus hominis } \\
\text { Amycolatopsis lurida } \\
\text { Kribbella catacumbae } \\
\text { Streptomyces nojiriensis } \\
\text { Streptomyces floccolosus } \\
\text { Streptomyces spororaveus }\end{array}$ \\
\hline & CSC13b & $\begin{array}{l}\text { Brevundimonas diminuta } \\
\text { Methylobacterium populi } \\
\text { Knoellia subterranea } \\
\text { Kribbella sancticallisti } \\
\text { Microbacterium phyllosphaerae } \\
\text { Streptomyces nojiriensis } \\
\text { Streptomyces avidinae }\end{array}$ \\
\hline & CsC13c & $\begin{array}{l}\text { Actinomadura fulvescens } \\
\text { Actinomadura cremea } \\
\text { Streptomyces avidinae }\end{array}$ \\
\hline \multirow{4}{*}{ 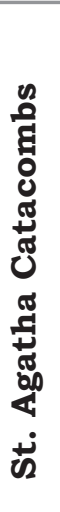 } & SA4 & $\begin{array}{l}\text { Streptomyces badius } \\
\text { Streptomyces flavidofuscus } \\
\text { Streptomyces sp. }\end{array}$ \\
\hline & SA7 & Bacillus aquimaris \\
\hline & SA19 & $\begin{array}{l}\text { Bacillus aquimaris } \\
\text { Nocardia uniformis } \\
\text { Streptomyces chungwensis }\end{array}$ \\
\hline & SA23 & Streptomyces badius \\
\hline
\end{tabular}

The dominant strains for each sample are shown in bold. 
2011b). We found different species of Bacillus or closely related spore-forming bacteria (Table 3) growing in chains and resembling filament-like structures (Fig. 1). The biomediated precipitation of mineral phases along the cells, as already demonstrated by different authors (Sanchez-Moral et al., 2003; Cañaveras et al., 2006, Zammit et al., 2011b) may explain the cotton-like aspect of this kind of alteration.

The high number of spore forming bacteria isolated from the Cave of Bats may be explained by an occasional organic input present on the surface due to medium impact of visitors in this site (20.000 visitors year ${ }^{-1}$ ) (Fernández-Cortes et al., 2008) and the low RH in most areas of this cave, which may induce sporulation. In St. Agatha catacombs spore forming bacteria belonging to the species $B$. aquimaris (Fig. 1), never found before in similar sites, were the most common and widely spread in the whole Catacombs while in Cave of Bats species such as B. simplex were the most widespread on the surfaces.

Due to the fact that members of the Proteobacteria were isolated only occasionally it is very difficult to hypothesize a biodeteriorative role. Their growth on lithic surfaces is related to the amount of water available. In the St. Callistus catacombs strains belonging to the Proteobacteria were isolated at a lower percentage with respect to the Actinobacteria and they seem to be unrelated to human contamination and be of environmental origin, intimately associated to the presence of cyanobacteria (Bruno et al., 2006). In fact, Proteobacteria are often associated with debris from cyanobacterial biofilms, and due to their metabolic versatility they may use several byproducts for their metabolic requirements (Albertano \& Urzì, 1999; Berg et al., 2009). Their number is relatively low in presence of metabolically active phototrophic microflora, while their amount increases dramatically in stress conditions such as after biocide treatments (Urzì et al., 2012).

Recently, the analysis and identification of microorganisms colonizing cultural heritage sites has been prolific through the application of molecular techniques for the rapid analysis of the microbial communities inhabiting a given environment (SchabereiterGurtner et al., 2002a, b; Laiz et al., 2003; Urzì et al,. 2003; Gonzalez \& Saiz Jimenez, 2005).

In this study we decided to focus our investigation to the portion of bacterial microflora that was able to grow in culture. In fact, in some cases, culturedependent techniques deserve more credit because once it has been established the role of a particular bacterium or a bacterial consortium in biodeterioration processes by a polyphasic approach in which microscopy, molecular tools and cultivation are combined, further study on the isolates can help answering some important questions: a) which strain is the responsible of specific alteration pattern? and, b) if more than one species is isolated in correspondence of he same pattern: how do the different members of this biodeteriorative community interact to form that alteration? In addition, during biocide and any other cleaning treatments, the use of isolated strains can help answer other important questions: i) how do bacteria behave in response to the treatment? and, ii) is the dose of treatment (either physical or chemical) effective for all the strains?
In addition, Fluorescent In Situ Hybridization (FISH) carried out with a combination of probes prepared according to the isolated strains may allow to answer to the two first questions, while experiments carried out both in laboratory conditions as well as in the field could help answer the biocide questions. Furthermore, through the isolation of bacterial strains, it becomes possible to discover strains with interesting taxonomies (Groth et al., 2005, 2006; Jurado et al., 2005a, 2005b; Urzì et al. 2008; Zammit et al., 2010, 2011a), and also strains with biotechnological potential including applications in art conservation.

In conclusion, the alteration of surfaces observed in the three sites and described as dark spots, green biofilms or white to grey veils/patinas were caused by the colonization of highly diverse bacterial associations (Albertano et al., 2003; Urzì et al., 2010; Zammit et al., 2009; 2011a,b)

According to Curtis and Sloan (2004), this diversity observed depends also on the so-called 'metacommunity'. This means that each microbial community will depend on the pioneer "microbe" that succeeds to colonize a given surface first; it will control the further process of formation and assessment of whole microbial community, hence it is clear that every process of colonization is different from the others. This fact may be the reason why even in samples taken only from a very short distance apart, the variability within the same species was very high (Urzì et al., 2010). In our opinion, this genetic variability within the species colonizing a particular site may be associated to a variety of different responses to biocide resistance that should be taken into account in the planning of conservation strategies of stone surfaces in subterranean environments.

\section{ACKNOWLEDGEMENTS}

This work was supported by the EU Programs EESD, the European Commission FP6 project CATS (contract EVK4-CT2000-00028), the COST G8 scientific mission (COST-STSM-G8-1435) and the University of Messina through Progetti di Ricerca di Ateneo P.R.A. years 2008-2010.

The Authors would like to express their gratitude for the kind cooperation of dott.ssa R. Giuliani of the "Pontificia Commissione di Archeologia Sacra (CdV)", at the Christian catacombs of Rome, to Fr. V. Camilleri MSSP, curator of St. Agatha Crypt and Catacombs in Malta and all the staff of Cave of Bats, in Spain.

The Authors would like to express a special thank to Prof. C. Saiz Jimenez and Prof. Diana Northup for their careful revision of the text and their valuable help to improve the manuscript.

\section{REFERENCES}

Agarossi G., Ferrari R. \& Monte M. 1985 - Microbial biodeterioration in the hypogea: the subterranean neo-pythagorean basilica of Porta Maggiore in Rome. In: Furlan V. (Ed)., $5^{\text {th }}$ International Congress on Deterioration and Conservation of Stone. Lausanne: Presses Polytechniques Romandes, 2: 597-605.

Albertano P. \& Bruno L., 2003 - The importance of light in the conservation of hypogean monuments. In: Saiz-Jimenez C. (Ed)., Molecular Biology and Cultural Heritage. Lisse: Swets \& Zeitlinger: 171-177. 
Albertano P., Moscone D., Palleschi G., Hermosín B., Saiz-Jimenez C., Sánchez-Moral S., HernándezMariné M., Urzi C., Groth I., Schroeckh V., Saarela M., Mattla Sandholm T., Gallon JR., Graziottin F., Bisconti F. \& Giuliani R., 2003 - Cyanobacteria attack rocks (CATS): control and preventive strategies to avoid damage caused by cyanobacteria and associated microorganisms in Roman hypogean monuments. In: Saiz-Jimenez C. (Ed)., Molecular Biology and Cultural Heritage. Lisse: Swets \& Zeitlinger: 151-162.

Albertano P. \& Urzì C., 1999 - Structural interactions among epilithic cyanobacteria and heterotrophic microorganisms in Roman Hypogea. Microbial Ecology, 38: 244-252. http://dx.doi.org/10.1007/s002489900174

Amann R., 2000 - Who is out there? Microbial aspects of diversity. Systematic and Applied Microbiology, 23: $125-136$. http://dx.doi.org/10.1016/S0723-2020(00)80039-9

Berg K.A., Lyra C., Sivonen K., Paulin L., Suomalainen S., Tuomi P. \& Rapala J., 2009 - High diversity of cultivable heterotrophic bacteria in association with cyanobacterial water blooms. The ISME Journal, 3: 314-315. http://dx.doi.org/10.1038/ismej.2008.110

Bruno L., Billi D., Urzì C. \& Albertano A., 2006 - Genetic characterization of epilithic cyanobacteria and their associated bacteria. Geomicrobiology Journal, 23: 293-297. http://dx.doi.org/10.1080/01490450600760732

Bunt J.S. \& Rovira A.D., 1955 - Microbiological studies of some subantartic soils. Journal of Soil Science, 6: 119-128.

http://dx.doi.org/10.1111/j.1365-2389.1955.tb00836.x

Cañaveras J.C., Cuezva S., Sanchez-Moral S., Lario J., Laiz L., Gonzalez J.M. \& Saiz-Jimenez C., 2006 - On the origin of fiber calcite on moonmilk deposits. Naturwissenschaften, 93: 27-32. http://dx.doi.org/10.1007/s00114-005-0052-3

Cuezva S., Sanchez-Moral S., Saiz-Jimenez C. \& Cañaveras J.C., 2009 - Microbial communities and associated mineral fabrics in Altamira Cave, Spain. International Journal of Speleology, 38: 83-92.

Curtis T.P. \& Sloan W.T., 2004 - Prokariotic diversity and its limits: microbial community structure in nature and implications for microbial ecology. Current Opinion in Microbiology, 7: 221-226. http://dx.doi.org/10.1016/j.mib.2004.04.010

Donachie S.P., Foster J.S. \& Brown M.V., 2007 - Culture clash: Challenging the dogma pf microbial diversity. The ISME Journal, 1: 97-102. http://dx.doi.org/10.1038/ismej.2007.22

Fernández-Cortés A., Calaforra J.M., Martín-Rosales W., González-Rios, M.J. 2008. Cavidades turísticas de Andalucía. In: Calaforra Chordi J.M \& Berrocal Pérez J.A. (Eds)., El Karst de Andalucía. Sevilla: Consejería de Medio Ambiente de la Junta de Andalucía: 105-116.

González J.M. \& Saiz-Jiménez C., 2005 - Application of molecular nucleic acid-based techniques for the study of microbial communities in monuments and artworks. International Microbiology, 8: 189-194.
Groth I. \& Saiz-Jimenez C., 1999 - Actinomycetes in hypogean environments. Geomicrobiology Journal, 16: 125-136. http:/ /dx.doi.org/10.1080/014904599270703

Groth I., Schumann P., Schuetze B., Gonzalez J.M., Laiz L., Saiz-Jimenez C. \& Stackebrandt E., 2005 - Isoptericola hypogeus sp. nov., isolated from the Roman catacomb of Domitilla. International Journal of Systematic and Evolutionary Microbiology, 55: 17151719. http://dx.doi.org/10.1099/ijs.0.63632-0

Groth I., Schumann P., Schutze B., Gonzalez J.M., Laiz, L., Suihko M-L. \& Stackebrandt E., 2006 Myceligenerans crystallogenes $s p$. nov., isolated from Roman catacombs. International Journal of Systematic and Evolutionary Microbiology, 56: 283-287. http://dx.doi.org/10.1099/ijs.0.63756-0

Gurtler V. \& Stanisich V.A., 1996 - New approaches to typing and identification of bacteria using the 16S23S rDNA spacer region. Microbiology, 142: 3-16. http://dx.doi.org/10.1099/13500872-142-1-3

Kuster E. \& Williams S.T., 1964 - Selection of media for isolation of Streptomyces. Nature, 22: 928929. http://dx.doi.org/10.1038/202928a0

Jurado V., Groth I., Gonzalez J.M., Laiz L., Schuetze B. \& Saiz-Jimenez C., 2005a-Agromyces italicus sp. nov., Agromyces humatus sp. nov. and Agromyces lapidis sp. nov., isolated from Roman catacombs. International Journal of Systematic and Evolutionary Microbiology, 55: 87125-13675. http://dx.doi.org/10.1099/ijs.0.63414-0

Jurado V., Laiz L., Gonzalez J.M., Hernandez-Marine M., Valens M. \& Saiz-Jimenez C. 2005b - Phyllobacterium catacumbae sp. nov., a member of the order 'Rhizobiales' isolated from Roman catacombs. International Journal of Systematic and Evolutionary Microbiology, 55:1487-1490. http://dx.doi.org/10.1099/ijs.0.63402-0

Laiz L., Piñar G., Lubitz W. \& Saiz-Jimenez C., 2003 - Monitoring the colonization of monuments by bacteria: cultivation versus molecular methods. Environmental Microbiology, 5: 72-74. http://dx.doi.org/10.1046/j.1462-2920.2003.00381.x

Nugari M.P., Pietrini A.M., Caneva G., Imperi F. \& Visca P., 2009 - Biodeterioration of mural paintings in a rocky habitat: The Crypt of the Original Sin (Matera, Italy). International Biodeterioration \& Biodegradation, 63: 705-711. http://dx.doi.org/10.1016/j.ibiod.2009.03.013

Pangallo D., Chovanová K., Drahovska H., De Leo F. \& Urzì C., 2009 - Application of fluorescence internal transcribed spacer-PCR (f-ITS) for the cluster analysis of bacteria isolated from air and deteriorated fresco surfaces. International Biodeterioration \& Biodegradation, 63: 868-872. http://dx.doi.org/10.1016/j.ibiod.2009.04.011

Rainey F.A., Ward-Raney N., Kroppenstedt R.M. \& Stackebrandt E., 1996 - The genus Nocardiopsis represents a phylogenetically coherent taxon and a distinct actinomycete lineage: proposal of Nocardiopsaceae fam. nov. International Journal of Systematic Bacteriology, 46: 1088-1092. http://dx.doi.org/10.1099/00207713-46-4-1088 
Reasoner D.J. \& Geldreich E.E., 1985 - A new medium for the enumeration and subculture of bacteria from potable water. Applied and Environmental Microbiology, 49: 1-7.

Roldán M. \& Hernández-Mariné M., 2009 - Exploring the secrets of the three-dimensional architecture of phototrophic biofilms in caves. International Journal of Speleology, 38: 41-53.

Sanchez-Moral S., Bedoya J., Luque L., Cañaveras J.C., Jurado V., Laiz L. \& Saiz-Jimenez C., 2003 Biomineralization of different crystalline phases by bacteria isolated from Catacombs. In: Saiz-Jimenez C. (Ed). -Molecular Biology and Cultural Heritage. Lisse: Swets \& Zeitlinger: 179-185.

Sanchez-Moral S., Luque L., Cuezva S., Soler V., Benavente D., Laiz L., Gonzalez J.M. \& Saiz-Jimenez C., 2005 - Deterioration of building materials in Roman catacombs: the influence of visitors. Science of the Total Environment, 349: 260-276. http://dx.doi.org/10.1016/j.scitotenv.2004.12.080

Salvadori O. \& Charola E., 2011 - Methods to prevent biocolonization and recolonization: an overview of current research for architectural and archeological heritage. In: Charola E., McNamara C., Koestler R.J. (Eds).. Biocolonization of stone: Control and preventive methods: Proceedings from the MCI Workshop Series. Washington: Smithsonian Institution Scholarly Press: 37-50.

Schabereiter-Gurtner C., Saiz-Jimenez C., Piñar G., Lubitz W. \& Rölleke S., 2002a - Altamira cave Paleolithic paintings harbor partly unknown bacterial communities. FEMS Microbiology Letters, 211: 7-11. http://dx.doi.org/10.1111/j.1574-6968.2002.tb11195.x

Schabereiter-Gurtner C., Saiz-Jimenez C., Piñar G., Lubitz W. \& Rölleke S., 2002b - Phylogenetic 16S rRNA analysis reveals the presence of complex and partly unknown bacterial communities in Tito Bustillo cave, Spain, and on its Paleolithic paintings. Environmental Microbiology, 4: 392-400. http://dx.doi.org/10.1046/j.1462-2920.2002.00303.x

Urzi C., Garcia-Valles M.T., Vendrell M. \& Pernice A., 1999 - Biomineralisation processes of the rock surfaces observed in field and in laboratory. Geomicrobiology Journal, 16: 39-54. http://dx.doi.org/10.1080/014904599270730

Urzi C., Brusetti L., Salamone P., Sorlini C., Stackebrandt E. \& Daffonchio D., 2001 - Biodiversity of Geodermatophilaceae isolated from altered stones and monuments in the Mediterranean basin. Environmental Microbiology, 3: 471-479. http://dx.doi.org/10.1046/j.1462-2920.2001.00217.x
Urzì C., De Leo F., Donato P. \& La Cono V., 2003 Study of microbial communities colonizing hypogean monument surfaces using nondestructive and destructive sampling methods. In: Koestler R.J., Koestler V.R., Charola A.E. \& Nieto-Fernandez F.E. (Eds)., Art, Biology, and Conservation: Biodeterioration of Works of Art. New York: The Metropolitan Museum of Art: 316-327.

Urzì C., De Leo F. \& Schumann P., 2008 - Kribbella catacumbae sp. nov. and Kribbella sancticallisti sp. nov., isolated from whitish-grey patinas in the catacombs of St. Callistus in Rome, Italy. International Journal of Systematic and Evolutionary Microbiology, 58: 2090-2097. http://dx.doi.org/10.1099/ijs.0.65613-0

Urzi C., De Leo F., Bruno L. \& Albertano P., 2010 - Microbial diversity in Paleolithic caves: a study case on the phototrophic biofilms of the Cave of Bats (Zuheros, Spain). Microbial Ecology, 60: 116- 129. http://dx.doi.org/10.1007/s00248-010-9710-x

Urzì C., Nasso R., Bruno L., De Leo F., Krakova L., Pangallo D. \& Albertano P., (in press) - Studio della diversità microbica su superfici di Catacombe prima e dopo interventi di trattamento con biocidi. Proceedings AIAR, Palermo.

Zammit G., De Leo F., Urzì C. \& Albertano P., 2009 A non-invasive approach to the polyphasic study of biodeteriogenic biofilms at St Agatha Crypt and Catacombs at Rabat, Malta. In: Meli G. (Ed)., Scienze e Patrimonio Culturale nel Mediterraneo Diagnostica e Conservazione: Atti del III Convegno Internazionale di Studi La materia e i segni della Storia. Palermo: Quaderni Palazzo Moltalbo, 15: 323-327.

Zammit G., Kaštovský J. \& Albertano P., 2010 - A first cytomorphological and molecular characterisation of a new Stigonematalean cyanobacterial morphotype isolated from Maltese catacombs. Algological Studies, 135: 1-14.

Zammit G., Billi D., Shubert E., Kaštovský J. \& Albertano P., 2011a - The biodiversity of subaerophytic phototrophic biofilms from Maltese hypogea. Fottea, 11: 187-201.

Zammit G., Sánchez-Moral S. \& Albertano P., 2011b - Bacterially mediated mineralisation processes lead to biodeterioration of artworks in Maltese catacombs. Science of the Total Environment, 409: 2773-2782.

http://dx.doi.org/10.1016/j.scitotenv.2011.03.008 
Appendix 1. Firmicutes isolated from the Ocean Cubicle in St. Callistus Catacombs, Zuheros Cave and St. Agatha Catacombs. Strains were clusterized on the basis of their ITS-PCR profile.

\begin{tabular}{|c|c|c|c|c|}
\hline $\begin{array}{l}\text { Nr. ITS } \\
\text { clusters }\end{array}$ & CSC 13 & Zuheros* & St. Agatha & $\begin{array}{l}\text { Nearest relative on the basis of } 16 \mathrm{~S} \\
\text { rDNA sequences similarity* }\end{array}$ \\
\hline 3 & & & $\begin{array}{l}\text { SA8col1 } \\
\text { SA17col1 } \\
\text { SA14col1 } \\
\text { SA10col1 } \\
\text { SA19col3 } \\
\text { Sa19col2 } \\
\text { SA7col1 } \\
\text { SA7col2 } \\
\end{array}$ & Bacillus aquimaris GU112997 (99.5%) \\
\hline 1 & & & $\underline{\text { SA12Acol1 }}$ & Bacillus cereus CP001177 (99.7\%) \\
\hline 1 & & & $\underline{\mathrm{Sa} 8 \mathrm{col} 2}$ & Bacillus endophyticus AF295302 (99\%) \\
\hline 2 & & $\underline{\mathrm{Z} 5 \mathrm{~b} 1} \underline{\mathrm{Z} 5 \mathrm{~b} 3}$ & & Bacillus firmus EF032672 (98.5\%) \\
\hline 1 & & $\underline{\mathrm{Z} 3 \mathrm{~b} 2}$ & & Bacillus licheniformis FJ458451 (99.5\%) \\
\hline 1 & & $\underline{\mathrm{Z} 3 \mathrm{a} 2}$ & & Bacillus mycoides AB021192 (98.7\%) \\
\hline 1 & & $\begin{array}{l}\underline{\mathrm{Z} 5 \mathrm{~b} 2} \\
\underline{\mathrm{Z} 5 \mathrm{~b} 5}\end{array}$ & & Bacillus pseudofirmus EU315248 (99.9\%) \\
\hline 2 & & $\begin{array}{l}\text { Z1a11, Z2a7, Z2a8, } \\
\text { Z3a1, Z3a3, Z3a4, } \\
\underline{Z 3 a 6}, Z 3 a 7, \underline{Z 3 b 1}, \\
\text { Z3b4, Z3b5, Z3b6, } \\
\text { Z3c2, Z3c3, Z4a2, } \\
\text { Z4a4, Z4a5, Z4a6, } \\
\text { Z4a7, Z4a8, Z4a9, } \\
\underline{Z 4 b 3}, Z 4 b 5, Z 4 b 6, \\
\text { Z5a1, Z5d2, Z6a4 } \\
\text { Z4b1 Z4b2 }\end{array}$ & & Bacillus simplex (DQ514314 98-100\%) \\
\hline 1 & & & $\begin{array}{l}\text { SA } 1 \text { col1 } \\
\text { SA } 1 \text { col2 }\end{array}$ & Bacillus sp. \\
\hline 1 & $\underline{\mathrm{CSC} 13 \mathrm{~h} 1}$ & Z6b8, $\underline{Z 8 a 6}$ & & Bacillus subtilis (AB0184886 100\%) \\
\hline 1 & & & $\underline{\mathrm{SA} 6 \mathrm{col} 1}$ & $\begin{array}{l}\text { Bacillus amyloliquefaciens CP00560 } \\
(99.6 \%)\end{array}$ \\
\hline 1 & $\underline{\mathrm{CSC} 13 \mathrm{a} 13}$ & & & $\begin{array}{l}\text { Humibacillus xanthopallidus AB282888 } \\
(99.7 \%)\end{array}$ \\
\hline 1 & & & $\underline{\mathrm{SA9}} \mathrm{col1}$ & Paenibacillus arenae AY839867 (98.7\%) \\
\hline 1 & $\underline{\operatorname{CSC} 13 \mathrm{~h} 2}$ & & & $\begin{array}{l}\text { Paenibacillus agaridevorans AJ345023 } \\
(97.6 \%)\end{array}$ \\
\hline 3 & & $\frac{\mathrm{Z2a} 1}{\underline{\mathrm{Z} 4 \mathrm{a} 3}}, \underline{\mathrm{Z2a} 3}, \underline{\mathrm{Z} 4 \mathrm{a} 1}$ & & Paenibacillus sp DQ444989 (99.2\%) \\
\hline 1 & & & $\underline{\mathrm{SA} 2 \mathrm{col} 1}$ & $\begin{array}{l}\text { Staphylococcus epidermidis CP000029 } \\
(100 \%)\end{array}$ \\
\hline 3 & $\frac{\mathrm{CSC} 13 \mathrm{a} 21}{\mathrm{CSC} 13 \mathrm{f} 4}$ & $\underline{\mathrm{Z} 5 \mathrm{a} 2}, \underline{\mathrm{Z} 5 \mathrm{a} 3}$ & & Staphylococcus hominis L37601 (99.7\%) \\
\hline
\end{tabular}

Underlined strains were those identified by sequencing of 16S rDNA; $\left({ }^{*}\right)$ data taken from Urzì et al., 2010. 
Appendix 2. Actinobacteria isolated from the Ocean Cubicle in St. Callistus Catacombs, Zuheros Cave and St. Agatha Catacombs. Strains were clusterized on the basis of their ITS-PCR profile. Streptomyces strains are reported in Appendix 3.

\begin{tabular}{|c|c|c|c|c|}
\hline $\begin{array}{l}\text { Nr. ITS } \\
\text { clusters }\end{array}$ & $\operatorname{csc13}$ & Zuheros* & St. Agatha & $\begin{array}{l}\text { Nearest relative on the basis of } 16 S \text { rDNA } \\
\text { sequences similarity* }\end{array}$ \\
\hline 1 & $\begin{array}{l}\text { CSC13b15 } \\
\text { CSC13b17 } \\
\end{array}$ & & & Actinomadura fulvescens AJ420137 (98.7\%) \\
\hline 1 & $\frac{\mathrm{CSC} 13 \mathrm{~b} 16}{\mathrm{CSC} 13 \mathrm{~b} 19}$ & & & Actinomadura cremea EU741181 (98.2\%) \\
\hline 1 & $\underline{\mathrm{CSC} 13 \mathrm{a} 12}$ & & & Amycolatopsis lurida (99.3\%) \\
\hline 1 & & $\underline{\mathrm{Z} 1 \mathrm{a} 7}, \mathrm{Z1b} 7$ & & Arthrobacter agilis X80748 (99.1\%) \\
\hline 2 & & $\begin{array}{l}\mathrm{Z1b5}, \underline{\mathrm{Z} 1 \mathrm{~b} 8} \\
\underline{\mathrm{Z1b} 12}, \mathrm{Z8 \textrm {a } 2} \\
\underline{\mathrm{Z1b} 2}\end{array}$ & & $\begin{array}{l}\text { Blastococcus saxobsidiens AJ316574 (BC } \\
\text { 412) (98.4\%) }\end{array}$ \\
\hline 1 & $\underline{\operatorname{CSC} 13 g 6}$ & & & $\begin{array}{l}\text { Brachybacterium conglomeratum AY167842 } \\
(98.8 \%)\end{array}$ \\
\hline 1 & & $\frac{Z 1 \mathrm{~b} 11}{Z 1 \mathrm{~b} 13}$ & & $\begin{array}{l}\text { Curtobacterium flaccumfaciens AY } 167854 \\
(99.8 \%)\end{array}$ \\
\hline 1 & & & $\underline{\mathrm{SA} 17 \mathrm{col} 2}$ & Gordonia soli AY995560 (97.6\%) \\
\hline 1 & & & $\underline{\mathrm{SA} 15 \mathrm{col1}}$ & Isoptericola variabilis FJ527726 (100\%) \\
\hline 1 & $\underline{\mathrm{CSC} 13 \mathrm{~b} 11}$ & & & Knoellia subterranea EU867301 (98.2\%) \\
\hline 2 & $\begin{array}{l}\frac{\text { CSC13a1 }}{\text { CSC13a2 }} \\
\text { CSC13a4 } \\
\text { CSC13a5, } \\
\text { CSC13a6 } \\
\text { CSC13a9, } \\
\text { CSC13a14 } \\
\end{array}$ & $\underline{\mathrm{Z} 1 \mathrm{~b} 3}$ & & $\begin{array}{l}\text { Kribbella catacumbae AM778575 (98.8- } \\
100 \%)^{\wedge}\end{array}$ \\
\hline 1 & & $\underline{\mathrm{Z} 2 \mathrm{~b} 1}$ & & Kribbella flavida AF005017 (97.1\%) \\
\hline 1 & $\begin{array}{l}\text { CSC13b3, } \\
\text { CSC13b17 } \\
\text { CSC13b18 }\end{array}$ & & & $\begin{array}{l}\text { Kribbella sancticallisti AM778577 (99.8- } \\
100 \%)^{\wedge}\end{array}$ \\
\hline 1 & $\frac{\mathrm{CSC} 13 \mathrm{~b} 6,}{\underline{\mathrm{CSC} 13 \mathrm{~b} 10}}$ & & & $\begin{array}{l}\text { Microbacterium phyllosphaerae EF } 143430 \\
(98.3 \%)\end{array}$ \\
\hline 4 & $\begin{array}{l}\text { CSC13e2, } \\
\text { CSC13f1 } \\
\text { CSC13f2, } \\
\text { CSC13i1 } \\
\text { CSC13i3, } \\
\text { CSC13b14 } \\
\text { CSC13g1 } \\
\text { CSC13g5 } \\
\end{array}$ & $\frac{\mathrm{Z2a} 2, \mathrm{Z3b3}}{\underline{\mathrm{Za} 1}}$ & $\underline{\mathrm{SA} 2 \mathrm{col} 2}$ & Micrococcus luteus AJ536198 (99.1\%-100\%) \\
\hline 1 & & $\frac{\mathrm{Z2a} 4}{\mathrm{Z} 2 \mathrm{~b} 4}$ & & Micrococcus lylae X80750 (98.1\%) \\
\hline 1 & & & $\underline{\mathrm{SA} 19 \mathrm{col1}}$ & Nocardia uniformis AF430044 (98,6\%) \\
\hline 1 & & $\underline{\mathrm{Zbb} 7}$ & & $\begin{array}{l}\text { Promicromonospora enterophila X83807 } \\
(98.9 \%)\end{array}$ \\
\hline 1 & & & $\frac{\text { SA13col1 }}{\text { Sa16col1 }}$ & $\begin{array}{l}\text { Pseudonocardia carboxidivorans } \mathrm{AF} 430044 \\
(100 \%)\end{array}$ \\
\hline 1 & & $\underline{\mathrm{Z} 1 \mathrm{a} 3}$ & & $\begin{array}{l}\text { Rhodococcus corynebacterioides AY } 167850 \\
(99.6 \%)\end{array}$ \\
\hline 1 & & $\underline{\mathrm{Z} 7 \mathrm{a} 10}$ & & Rhodococcus erythropolis AY281121 (99.1\%) \\
\hline 1 & & $\underline{Z 1 a 4}$ & & Rhodococcus fascians DQ870746 (98.8\%) \\
\hline
\end{tabular}

Underlined strains were those identified by sequencing of 16S rDNA; $\left(^{*}\right)$ data taken from Urzì et al., 2010. (^) strains described by two of the Authors (Urzi et al., 2008). 
Appendix 3. Streptomyces isolated from the Ocean Cubicle in St. Callistus Catacombs, Zuheros Cave and St. Agatha Catacombs. Strains were clusterized on the basis of their ITS-PCR profile.

\begin{tabular}{|c|c|c|c|c|}
\hline $\begin{array}{l}\text { Nr. ITS } \\
\text { clusters }\end{array}$ & $\operatorname{csc13}$ & Zuheros* & St. Agatha & $\begin{array}{l}\text { Nearest relative on the basis of } 16 S \text { rDNA } \\
\text { sequences similarity* }\end{array}$ \\
\hline 1 & $\begin{array}{l}\frac{\mathrm{CSC} 13 \mathrm{~b} 20}{\mathrm{CSC} 13 \mathrm{c} 5} \\
\mathrm{CSC} 13 \mathrm{c} 7 \\
\mathrm{CSC} 13 \mathrm{c} 9\end{array}$ & & & Streptomyces avidinae AB184395 (99.5\%) \\
\hline 1 & & & $\begin{array}{l}\text { SA4col2, } \\
\text { SA4col3, } \\
\text { Sa23col5, } \\
\text { SA4col4, } \\
\text { Sa23col2, } \\
\text { SA8col3, } \\
\text { Sa9col2 }\end{array}$ & Streptomyces badius AY999783 (99.7-100\%) \\
\hline 1 & & $\frac{\frac{Z 7 a 4}{Z 7 a 5}}{Z 7 a 6}$ & & Streptomyces caeruleus EF178698 (99.5\%) \\
\hline 1 & & & $\underline{\mathrm{SA} 19 \mathrm{col} 4}$ & $\begin{array}{l}\text { Streptomyces chungwensis AY382292 } \\
(99.7 \%)\end{array}$ \\
\hline 1 & & & $\begin{array}{l}\text { SA4col1, } \\
\text { SA4col1f }\end{array}$ & Streptomyces flavidofuscus AY999914 (100\%) \\
\hline 1 & & $\begin{array}{l}\text { Z1a8, Z2a5, } \\
\text { Z2a6, Z2b6, } \\
\text { Z2b8, Z2b9, } \\
\text { Z2b10 }\end{array}$ & & Streptomyces flavolimosus EF688620 (100\%) \\
\hline 1 & $\underline{\mathrm{CSC} 13 \mathrm{~d} 3}$ & & & $\begin{array}{l}\text { Streptomyces mutomycini AAJ781357 } \\
(99.5 \%)\end{array}$ \\
\hline 1 & $\frac{\operatorname{CSC} 13 \mathrm{~d} 2}{\mathrm{CSC} 13 \mathrm{~d} 4}$ & Z1a1, Z1a9 & & Streptomyces griseus AY207610 (99.6\%) \\
\hline 1 & & $\frac{\mathrm{Z} 6 \mathrm{~b} 9}{\underline{\mathrm{Z} 7 \mathrm{a} 12}, \underline{\mathrm{Z7a} 13}, \underline{\mathrm{Z7a} 3}}$ & & Streptomyces laceyi AY094367 (98.2\%) \\
\hline 3 & $\begin{array}{l}\frac{\mathrm{CSC} 13 \mathrm{a} 4}{\mathrm{CSC} 13 \mathrm{a} 7} \\
\mathrm{CSC} 13 \mathrm{a} 11 \\
\mathrm{CSC} 13 \mathrm{a} 21 \\
\mathrm{CSC} 13 \mathrm{a} 23 \\
\mathrm{CSC} 13 \mathrm{a} 27 \\
\mathrm{CSC} 13 \mathrm{a} 24 \\
\mathrm{CSC} 13 \mathrm{~b} 18 \\
\end{array}$ & & & $\begin{array}{l}\text { Streptomyces nojiriensis AJ781355 (99.8\%- } \\
100 \%)\end{array}$ \\
\hline 1 & & & $\underline{\mathrm{SA} 18 \mathrm{col1}}$ & Streptomyces peucetis AB045887 (99.5\%) \\
\hline 1 & $\underline{\mathrm{CSC} 13 \mathrm{a} 12}$ & & & Streptomyces floccolosus AB8427297 (97.6\%) \\
\hline 1 & & & $\frac{\mathrm{SA} 3 \mathrm{col11}}{\mathrm{SA} 4 \mathrm{col} 6}$ & Streptomyces sp. AJ315072 (99.5\%) \\
\hline 1 & $\underline{\mathrm{CSC} 13 \mathrm{a} 3}$ & & & Streptomyces spororaveus AJ781370 (100\%) \\
\hline
\end{tabular}

Underlined strains were those identified by sequencing of 16S rDNA; $\left({ }^{*}\right)$ data taken from Urzì et al., 2010. 